\title{
Losy edukacyjne i zawodowe absolwentów techników i zasadniczych szkół zawodowych
}

DOI: 10.47050/65591814.136-166

Michał Sitek, Jędrzej Stasiowski

W rozdziale przedstawiono główne wyniki pilotażowej rundy ogólnopolskiego badania absolwentów szkół zawodowych zrealizowanego przez Instytut Badań Edukacyjnych w latach 2015-2017. Badanie to umożliwiło odtworzenie historii zawodowej i edukacyjnej absolwentów w trakcie 22 miesięcy po zakończeniu nauki, analizę danych dotyczących różnych aspektów zatrudnienia, wynagrodzenia i satysfakcji z pracy. Wyniki pokazują znaczne zróżnicowanie sytuacji absolwentów zasadniczych szkół zawodowych i techników, na co wpływa przede wszystkim kontynuowanie nauki przez absolwentów techników na studiach. Absolwenci, którzy podejmują pracę, rzadko zmieniają pracodawcę. Na różnice w ścieżkach zawodowo-edukacyjnych w niewielkim stopniu wpływa obszar kształcenia. W pewnym stopniu przekłada się on natomiast na różnice w zarobkach, zgodność wykonywanej pracy z wykształceniem oraz satysfakcję z pracy.

\section{Słowa kluczowe:}

losy absolwentów

przejście z edukacji na rynek pracy

kształcenie zawodowe 


\section{Educational and labour market careers of graduates of technical and basic vocational schools}

DOI: $10.47050 / 65591814.136-166$

Michał Sitek, Jędrzej Stasiowski

The chapter presents main results of the pilot graduate tracer study conducted among graduates of vocational schools in Poland by the Educational Research Institute in the years 2015-2017. Educational and occupational histories of the first 22 months after graduation were reconstructed and analyses of different aspects of employment, earnings and job satisfaction. The results shown substantial differences among graduates of basic vocational schools and technical schools that are mostly related to the entrance of some of the graduates of technical schools to tertiary education. Graduate that found employment rarely change their employers. The educational and occupational trajectories are only weakly affected by the field of education. The latter factor is more important in explaining differences in earnings, matching of jobs to one's education and job satisfaction.

Keywords:

graduate tracking

school-to-work transition

vocational education 
Przejście z edukacji do pracy jest ważnym okresem zarówno $z$ indywidualnego, jak i społecznego punktu widzenia. Łatwość znajdywania pracy odpowiadającej kompetencjom i oczekiwaniom absolwentów jest ważnym elementem oceny jakości systemu kształcenia zawodowego. Przejście na rynek pracy nie jest uwarunkowane wyłącznie tylko indywidualnymi decyzjami i umiejętnościami absolwentów, ale też szerszym kontekstem makroekonomicznym i sytuacją na lokalnym rynku pracy. Znaczenie mają też instytucjonalne powiązania między systemem edukacji i rynku pracy.

Jak pokazano wcześniej, na losy absolwentów na rynku pracy wpływa nie tylko podaż absolwentów i osób będących już na rynku pracy z konkretnym rodzajem wykształcenia, ale również popyt na określone kwalifikacje i kompetencje ze strony pracodawców. Ten rozdział uzupełnia analizy przekrojowe dotyczące funkcjonowania osób młodych na rynku pracy i ich zmian w czasie, przedstawione we wcześniejszych rozdziałach, o perspektywę indywidualnych karier zawodowych i edukacyjnych absolwentów. Przejście z edukacji na rynek pracy widziane $z$ indywidualnej perspektywy jest złożonym procesem. Absolwenci mogą nie tylko różnić się ze względu na długość poszukiwania zatrudnienia, ale mogą też podjąć decyzję o łączeniu pracy z edukacją lub odłożyć poszukiwanie pracy na później i zdobywać dodatkowe kwalifikacje. Ten ostatni wybór ma duże znaczenie w Polsce, gdzie większość absolwentów kształcących się zawodowo zdobywa wiedzę i kompetencje w technikach, które uczą nie tylko umiejętności zawodowych, ale także realizują pełny program edukacji ogólnej przygotowującej do kontynuacji kształcenia na poziomie wyższym. Na znaczenie ujęcia procesu przechodzenia $z$ edukacji na rynek pracy w dynamicznej perspektywie wskazuje też bogata literatura podkreślająca znaczny wpływ wczesnych doświadczeń na rynku pracy na dalszy przebieg kariery (Arulampalam, Booth, Taylor 2000; Gregg, Tominey 2005) lub satysfakcję z życia (Clark, Georgellis, Sanfey 2001; Knabe, Rätzel 2011).

Dane wykorzystane do dalszych analiz pochodzą z rundy pilotażowej badania zrealizowanego w okresie od 13 maja do 30 września 2017 r. w ramach projektu Monitorowanie Losów Edukacyjno-Zawodowych Absolwentów i Młodych Dorosłych (MLEZAMID) współfinansowanego ze środków Unii Europejskiej w ramach Europejskiego Funduszu Spo- 
łecznego1, który stanowi kontynuację przeprowadzonego w 2015 r. przez Instytut Badań Edukacyjnych Badania Losów Absolwentów Szkół Zawodowych (BLASZ). Rundę pilotażową badania MLEZAMID zrealizowano metodą CAPI na próbie losowej 5678 absolwentów 140 techników, 134 zasadniczych szkół zawodowych oraz 39 szkół policealnych, którzy wiosną 2015 r. byli uczniami ostatnich klas w swoich szkołach (wówczas wzięli udział w badaniu BLASZ). $Z$ analiz prezentowanych w tym rozdziale wyłączono absolwentów szkół policealnych z 2015 r., a w niektórych wypadkach ograniczono się wyłącznie do opisu sytuacji absolwentów, którzy mieli jakiekolwiek doświadczenia na rynku pracy. Dlatego wielkości podawane na prezentowanych wykresach i tabelach są niższe od wspomnianej powyżej liczebności próby.

Niniejszy rozdział przedstawia aktywność ekonomiczną absolwentów oraz ich pierwsze doświadczenia zawodowe. Analiza obejmuje okres od czerwca 2015 r. do kwietnia 2017 r., czyli 22 miesiące po czerwcu 2015 r., który umownie traktujemy jako miesiąc zakończenia nauki. Pytania kwestionariusza ankiety umożliwiły dokładne odtworzenie historii zawodowej i edukacyjnej respondentów w poszczególnych miesiącach oraz charakterystykę ich pierwszego miejsca pracy.

Ogólna charakterystyka losów edukacyjnych i zawodowych absolwentów techników i zasadniczych szkół zawodowych

Przejście z edukacji na rynek pracy można analizować na wiele sposobów. Szczególnie ważne są analizy uwzględniające zmianę sytuacji osób wchodzących na rynek pracy w czasie. Jedną z często wykorzystywanych do tego celu technik jest analiza sekwencji, której istotą jest porównywanie statusów edukacyjno-zawodowych, w jakich znajdują się absolwenci w określonym czasie (np. w kolejnych miesiącach po zakończeniu nauki). Pozwala to na wyróżnienie podobnych wzorców karier zawodowo-edukacyjnych. W analizach wykorzystano dane z pilotażowej rundy monitorowania losów absolwentów dotyczące absolwentów zasadniczych szkół zawodowych i techników, zawierające informacje o ich sytuacji na rynku pracy i rynku edukacyjnym w 22 miesiące po zakończeniu nauki. We wstępnych analizach wyróż-

W części rozdziału dotyczącej prac dorywczych, pierwszej pracy oraz zgodności pracy z wykształceniem wykorzystano wnioski z analizy zawarte w raporcie z tych badań: Bulkowski i in. 2017. 
niamy cztery rodzaje sytuacji, w których mogą być absolwenci w kolejnych miesiącach po zakończeniu nauki. Wiążą się one z ich aktywnością na rynku pracy i rynku edukacyjnym: absolwenci mogą pracować, uczyć się, łączyć pracę z nauką bądź też nie pracować i nie uczyć się.

Wykres 1. Odsetek absolwentów z 2015 r. w podziale na status edukacyjny i zawodowy w kolejnych miesiącach po czerwcu 2015 r.

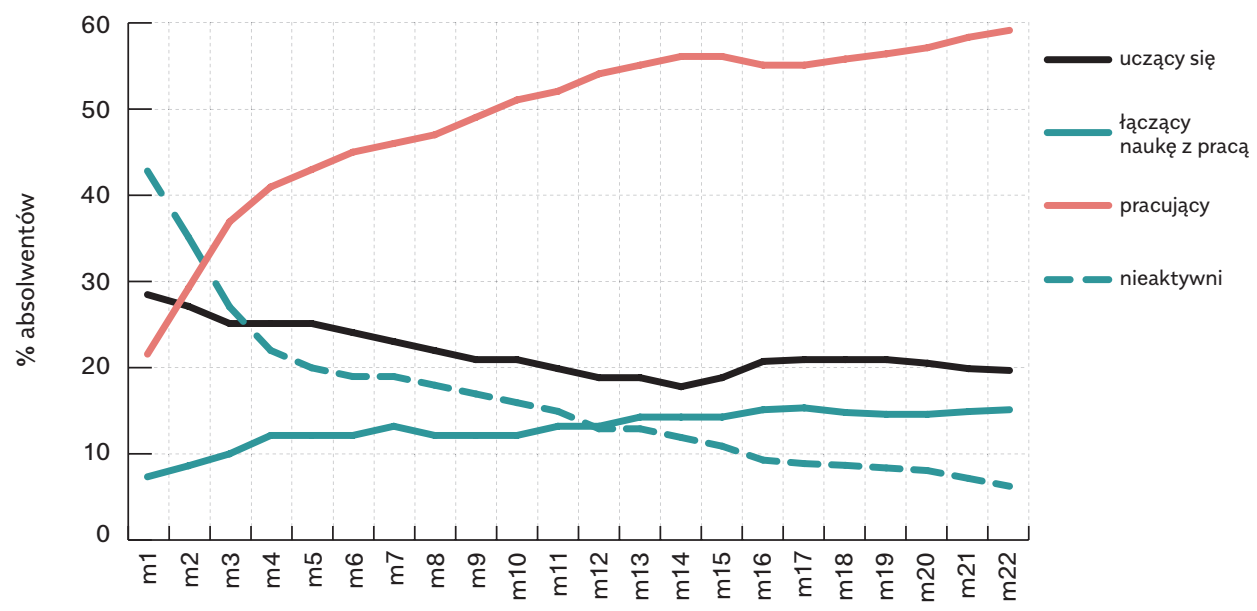

Źródło: runda pilotażowa badania MLEZAMID.

Powyższy wykres ilustruje sytuację absolwentów w sposób przekrojowy, nie podając informacji o sytuacji poszczególnych osób. Przykładowo rok po zakończeniu nauki pracowało ok. 55\% absolwentów, dodatkowe kilkanaście procent łączyło pracę z nauką, a ok. $20 \%$ wyłącznie kształciło się. Z punktu widzenia analizy losów absolwentów ważną informacją są zmiany w zatrudnieniu i aktywnościach edukacyjnych poszczególnych osób. Sekwencje sytuacji edukacyjno-zawodowej dla przykładowych absolwentów przedstawiono na wykresie 2. Absolwent oznaczony numerem 1 znajduje zatrudnienie i podejmuje pracę bezpośrednio w pierwszym miesiącu po zakończeniu nauki. Absolwent oznaczony numerem 5 bezpośrednio po szkole kontynuuje naukę (np. po technikum dostaje się na studia) - w takich przypadkach przyjęto założenie, że również $w$ lipcu, sierpniu i wrześniu pozostaje w edukacji. Zdarza się jednak, że absolwent pozostaje bez pracy przez 
określony czas (absolwent 4) lub ma okresy łączenia pracy z nauką (absolwenci 2 i 3 ).

Wykres 2. Przykładowe sekwencje edukacyjno-zawodowe

absolwentów szkół zawodowych

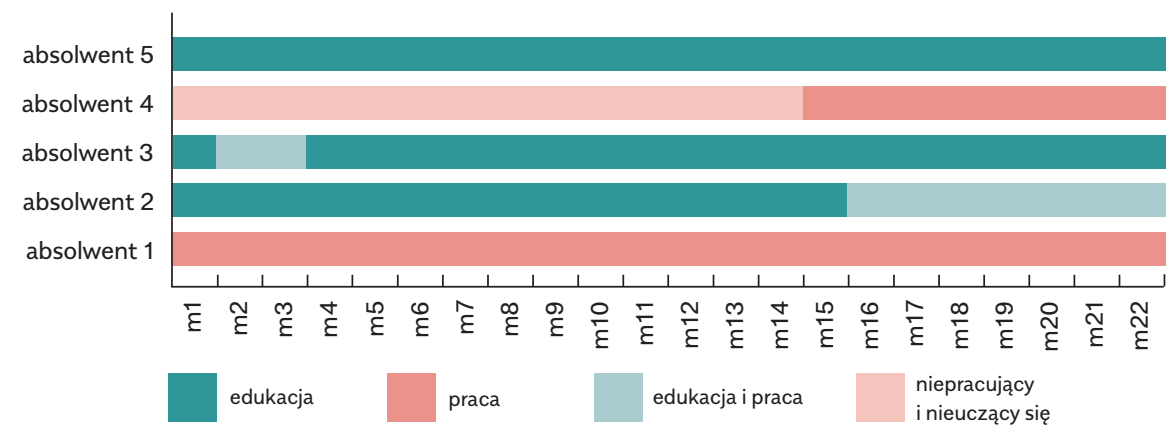

Źródło: runda pilotażowa badania MLEZAMID.

W analizach tego typu danych porównania między sekwencjami dokonuje się na podstawie algorytmów wykorzystujących różne sposoby wyliczania różnic między sekwencjami. Najczęściej stosowaną techniką jest technika optymalnego dopasowania (optimal matching) polegająca na porównaniu kosztów upodabniania sekwencji, np. liczby zmian (usunięć, zamian), których trzeba dokonać, by sekwencje były takie same. W analizach wykorzystano standardową technikę optymalnego dopasowania, w której przyjęto stały koszt zamiany/wstawiania poszczególnych pozycji2.

Mając wyliczone dystanse, można przystąpić do grupowania sekwencji. W analizach testowano dwie metody grupowania, popularną metodę Warda oraz algorytm PAM (partitioning around medoids, algorytm k-medoidów), w którym celem jest znalezienie takiego rozwiązania, które minimalizuje odmienności elementów w poszczegól-

2 W przypadku analizowanych danych najpopularniejsze techniki dają podobne wyniki: przy stałych kosztach korelacje techniki optymalnego dopasowania z dystansami wyliczonymi $z$ wykorzystaniem innych algorytmów to: dystans Hamminga: $r=0,92$, subsequence vector representation-based metric: $r=0,81$, longest common subsequence: $r=1,0$. 
nych parach. W obu metodach statystyki dopasowania wskazują na cztery skupienia. Obie metody dają podobne wyniki, a różnice dotyczą przydziału osób do grupy pracujących i łączących pracę z nauką.

Uzyskane grupowanie przedstawiono na poniższym wykresie. Osoby skategoryzowane jako pracujące relatywnie szybko znalazły zatrudnienie i pracowały przez większość analizowanego okresu. Odróżnia je to od osób skategoryzowanych jako osoby nieaktywne, które przez większość analizowanych 22 miesięcy nie uczyły się i nie pracowały bądź które znalazły pracę dopiero po dłuższym okresie nieaktywności. W tej kategorii są też nieliczne osoby, które przerwały edukację lub, po roku przerwy, podjęły naukę na studiach lub w szkole policealnej. W kategorii osób łączących pracę z nauką są osoby, które studiowały lub uczyły się w szkole policealnej, godząc zdobywanie wykształcenia z pracą bądź znajdując zatrudnienie $w$ relatywnie krótkim czasie. W czwartej grupie są osoby, których jedyną lub dominującą aktywnością była edukacja. 
Wykres 3. Sekwencje edukacyjno-zawodowe absolwentów

w podziale na grupy absolwentów wyróżnione w analizie skupień
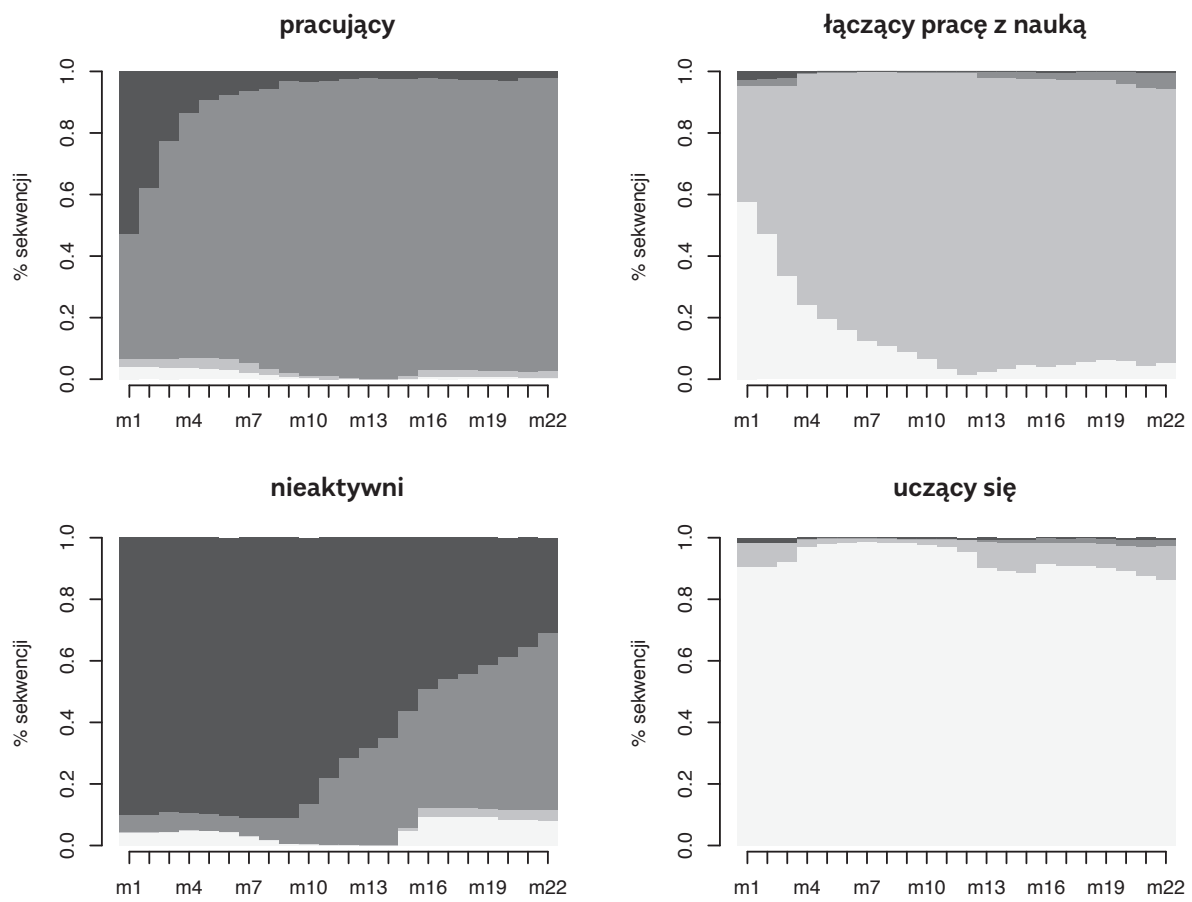

$$
\begin{array}{ll}
\square \text { edukacja } & \square \text { praca } \\
\square \text { edukacja i praca } & \square \text { niepracujący i nieuczący się }
\end{array}
$$

Źródło: runda pilotażowa badania MLEZAMID.

Do tej pory dane dotyczące absolwentów zasadniczych szkół zawodowych i techników analizowano łącznie. Jednak z oczywistych względów obie te grupy są nieporównywalne. Absolwenci techników w znacznej części kontynuują naukę na studiach i jest to bardziej naturalna ścieżka kariery niż w przypadku absolwentów szkół zawodowych.

Przynależność absolwentów do poszczególnych grup różni się w zależności od rodzaju szkoły, którą ukończyli. Wśród absolwentów techników jest więcej osób uczących się: stanowią oni, wraz z osobami łączącymi pracę z nauką, ok. $36 \%$ badanych. Dla absolwentów zasadniczych szkół zawodowych dominującą ścieżką kariery jest poszukiwanie pracy, ale $25 \%$ spośród nich zalicza się do kategorii związanych z kontynuacją 
edukacji. Wśród absolwentów zasadniczych szkół zawodowych jest też nieco więcej osób sklasyfikowanych jako pozostające poza edukacją i pracą.

Tabela 1. Przynależność absolwentów poszczególnych szkół

do czterech kategorii statusu edukacyjno-zawodowego (w \%)

\begin{tabular}{|c|c|c|c|}
\hline & $\begin{array}{c}\text { zasadnicza } \\
\text { szkoła zawodowa }\end{array}$ & technikum & cała próba \\
\hline pracujący & 55,7 & 48 & 50,6 \\
\hline łączący pracę z nauką & 13,8 & 11,5 & 12,3 \\
\hline uczący się & 10,6 & 25,2 & 20,2 \\
\hline nieaktywni & 19,9 & 15,3 & 16,9 \\
\hline ogółem & 100 & 100 & 100 \\
\hline $\mathrm{N}$ & 855 & 1655 & 2510 \\
\hline
\end{tabular}

Źródło: runda pilotażowa badania MLEZAMID.

Aż 33\% absolwentów zasadniczych szkół zawodowych i prawie 42\% absolwentów techników przez cały 22-miesięczny okres obserwacji nie zmieniało swojego statusu: wyłącznie pracowało, uczyło się, łączyło pracę z nauką lub pozostawało nieaktywne. Zasadnicze szkoły zawodowe i technika różniły się zwłaszcza pod względem odsetka osób, które pozostawały przez cały czas wyłącznie w edukacji: $w$ ramach kategorii "uczący się" w technikach było to aż $76 \%$ osób zakwalifikowanych do tej kategorii, natomiast w zasadniczych szkołach zawodowych $57 \%$.

Jakie czynniki różnicują osoby znajdujące się w poszczególnych grupach absolwentów? Odpowiedź na to pytanie można uzyskać, przeprowadzając analizę regresji przewidującej wpływ różnych zmiennych na szanse znalezienia się w poszczególnych kategoriach absolwentów. W przypadku zasadniczych szkół zawodowych spośród uwzględnionych zmiennych największy wpływ ma płeć. W przypadku kobiet (wśród badanych absolwentów zasadniczych szkół zawodowych ok. 38\% absolwentów) zmniejsza się prawdopodobieństwo pozostawania wyłącznie w zatrudnieniu a zwiększa się prawdopodobieństwo pozostawania wyłącznie w edukacji. Drugim pod względem wagi czynnikiem jest posiadanie zatrudnienia przed ukończeniem nauki. Zadeklarowało je ok. $10 \%$ absolwentów. Przy kontroli pozostałych zmiennych posiadanie 
pracy zwiększa prawdopodobieństwo łączenia pracy z nauką o $12 \%$ i zmniejsza prawdopodobieństwo trafienia do kategorii osób nieaktywnych (lub zaczynających pracę po dłuższym okresie nieaktywności) o 13\%. Na przynależność do poszczególnych kategorii wpływa też posiadanie dyplomu potwierdzającego kwalifikacje zawodowe ( $w$ analizie uwzględniono jedynie te dyplomy, które absolwenci uzyskali do 2015 r., a więc roku ukończenia nauki - ich uzyskanie zadeklarowało ok. $90 \%$ absolwentów). Osoby z dyplomem, porównywalne z innymi absolwentami pod względem innych charakterystyk, mają większe szanse na pozostawanie wyłącznie w zatrudnieniu po zakończeniu nauki. Jest też mniej prawdopodobne, że pozostaną poza rynkiem pracy i edukacją, mają też mniejsze szanse na pozostawanie wyłącznie w systemie edukacji. Znaczenie mają także warunki na rynku pracy (w modelu uwzględnione w postaci wskaźnika bezrobocia osób w wieku 25-34 lata w powiecie z 2014 r., a więc $w$ roku poprzedzającym ukończenie szkoły). Jedno odchylenie standardowe (ok. 3,3 pkt. proc.) wskaźnika bezrobocia zmniejsza o ok. $5 \%$ prawdopodobieństwo pozostawania wyłącznie w zatrudnieniu i w podobnym stopniu zwiększa prawdopodobieństwo znalezienia się w kategorii osób nieuczących się i pozostających bez pracy (not in employment education or training - NEET). Obszar ukończonego wykształcenia ma niewielki wpływ na przynależność do poszczególnych kategorii absolwentów³. 
Tabela 2. Wpływ wybranych zmiennych na prawdopodobieństwo zatrudnienia i nauki absolwentów zasadniczych szkół zawodowych (średnie efekty krańcowe w logistycznej regresji wielomianowej)

\begin{tabular}{|c|c|c|c|c|}
\hline & pracujący & $\begin{array}{c}\text { łączący } \\
\text { pracę z nauką }\end{array}$ & uczący się & nieaktywni \\
\hline płeć $($ kobieta = 1) & $-0,167^{\star \star}$ & 0,042 & $0,107^{*}$ & 0,018 \\
\hline \multicolumn{5}{|l|}{ obszar kształcenia } \\
\hline $\mathrm{BU}$ vs $\mathrm{AU}$ & $-0,012$ & $-0,008$ & $-0,002$ & 0,022 \\
\hline $\mathrm{EE}, \mathrm{MG}$ vs $\mathrm{AU}$ & 0,034 & 0,016 & 0,037 & $-0,086$ \\
\hline$T G, R, M$ vs $A U$ & $-0,065$ & $0 ., 021$ & 0,030 & 0,014 \\
\hline $\mathrm{EE}, \mathrm{MG}$ vs $\mathrm{BU}$ & 0,046 & 0,024 & 0,039 & $-0,109$ \\
\hline $\mathrm{TG}, \mathrm{R}, \mathrm{M}$ vs $\mathrm{BU}$ & $-0,053$ & 0,029 & 0,032 & $-0,008$ \\
\hline$T G, R, M$ vs EE, MG & $-0,098$ & 0,005 & $-0,007$ & $0,101^{*}$ \\
\hline $\begin{array}{l}\text { dyplom potwierdzający kwalifikacje } \\
\text { uzyskany w } 2015 \text { r. (tak = 1) }\end{array}$ & $0,068^{* * *}$ & $-0,002$ & $-0,022^{\star *}$ & $-0,044^{\star \star \star}$ \\
\hline powtarzanie klasy (tak = 1) & $-0,030$ & $-0,008$ & 0,076 & $-0,038$ \\
\hline $\begin{array}{l}\text { posiadanie pracy przed ukończeniem } \\
\text { nauki (przed czerwcem } 2015 \text { r.) (tak = 1) }\end{array}$ & 0,074 & $0,124^{\star}$ & $-0,063$ & $-0,135^{\star *}$ \\
\hline $\begin{array}{l}\text { udział bezrobotnych w wieku 25-34 lata } \\
\text { w } 2014 \text { r. w powiecie zamieszkania } \\
\text { (+ } 1 \text { odchylenie standardowe) }\end{array}$ & $-0,053^{*}$ & $-0,009$ & 0,018 & $0,044^{*}$ \\
\hline
\end{tabular}

${ }^{*} p<0,05,{ }^{* \star} p<0,01,{ }^{* \star *} p<0,001$. Skróty obszarów kształcenia: AU - obszar administracyjno-usługowy; BU - obszar budowlany; EE, MG - obszary elektroniczno-elektryczny i mechaniczno-górniczy; TG, R, M - obszary turystyczno-gastronomiczny, rolny i medyczny.

Źródło: runda pilotażowa badania MLEZAMID.

Uzyskane wyniki warto porównać z wynikami dla absolwentów techników. Efekt płci różnicuje absolwentów w podobny sposób jak w zasadniczych szkołach zawodowych. Bycie kobietą (ok. 39\% absolwentów techników) zmniejsza prawdopodobieństwo pozostawania wyłącznie w zatrudnieniu i oznacza większe prawdopodobieństwo funkcjonowania poza rynkiem pracy (wyłącznie w edukacji lub nieaktywności). Silniejszy niż w przypadku absolwentów zasadniczych szkół zawodowych jest też efekt posiadania pracy przed ukończeniem szkoły (podobnie jak w przypadku zasadniczych szkół zawodowych ok. 10\% 
absolwentów). Jest mniej prawdopodobne, że osoby mające pracę przed zakończeniem nauki będą wyłącznie się uczyć lub pozostawać poza rynkiem pracy i edukacji, i bardziej prawdopodobne, że będą wyłącznie pracować bądź łączyć pracę z nauką.

W wynikach dotyczących absolwentów techników bardziej wyraźny jest negatywny wpływ powtarzania klasy na dalsze kształcenie: osoby mające za sobą doświadczenie powtarzania klasy (ok. 4\% absolwentów techników) z ok. $14 \%$ mniejszym prawdopodobieństwem będą wyłącznie w edukacji. Czynnik ten nie miał znaczenia w przypadku absolwentów zasadniczych szkół zawodowych, w przypadku których można zauważyć bardzo słaby pozytywny wpływ powtarzania klasy na kontynuowanie edukacji. Świadczy to o różnicach w selekcji do dalszej edukacji w przypadku absolwentów różnych typów szkół.

Obserwujemy także niewielki, ale statystycznie istotny efekt posiadania dyplomu potwierdzającego kwalifikacje zawodowe (81\% absolwentów): posiadanie kwalifikacji pozytywnie wpływa na pozostawanie wyłącznie w edukacji i zmniejsza ryzyko bycia w kategorii NEET. Nie wpływa natomiast na szanse pozostawania wyłącznie w zatrudnieniu i łączenia pracy z nauką.

Wpływ poziomu bezrobocia w przypadku absolwentów techników jest inny niż w przypadku absolwentów zasadniczych szkół zawodowych. W przypadku techników wyższe bezrobocie nie sprzyja pozostawaniu w edukacji lub łączeniu edukacji z nauką, ale zwiększa prawdopodobieństwo posiadania pracy lub pozostawania poza systemem edukacji i pracy.

Wśród absolwentów techników występują też nieco większe różnice między obszarami kształcenia: największe w przypadku porównania obszarów turystyczno-gastronomicznego, rolnego i medycznego (38\% absolwentów techników) z elektroniczno-elektrycznym i mechaniczno-górniczym. Kształcenie w ramach tego pierwszego obszaru w większym stopniu wpływa na pozostawanie wyłącznie w zatrudnieniu i zmniejsza szanse na pozostawanie wyłącznie w edukacji. 
Tabela 3. Wpływ wybranych zmiennych na prawdopodobieństwo zatrudnienia i nauki absolwentów techników (średnie efekty krańcowe w logistycznej regresji wielomianowej)

\begin{tabular}{|c|c|c|c|c|}
\hline & pracujący & $\begin{array}{c}\text { łączący } \\
\text { pracę z nauką }\end{array}$ & uczący się & nieaktywni \\
\hline płeć $($ kobieta $=1)$ & $-0,162^{\star \star \star}$ & 0,012 & $0,082^{\star \star}$ & $0,068^{\star *}$ \\
\hline \multicolumn{5}{|l|}{ obszar kształcenia } \\
\hline $\mathrm{BU}$ vs $\mathrm{AU}$ & 0,026 & $-0,102^{*}$ & 0,011 & 0,065 \\
\hline $\mathrm{EE}, \mathrm{MG}$ vs $\mathrm{AU}$ & $-0,046$ & $-0,086^{*}$ & 0,090 & 0,043 \\
\hline $\mathrm{TG}, \mathrm{R}, \mathrm{M}$ vs $\mathrm{AU}$ & 0,080 & $-0,054$ & $-0,045$ & 0,019 \\
\hline $\mathrm{EE}, \mathrm{MG}$ vs $\mathrm{BU}$ & $-0,072$ & 0,016 & 0,079 & $-0,022$ \\
\hline $\mathrm{TG}, \mathrm{R}, \mathrm{M}$ vs BU & 0,054 & 0,048 & $-0,056$ & $-0,046$ \\
\hline$T G, R, M$ vs $E E, M G$ & $0,126^{\star *}$ & 0,032 & $-0,134^{\star \star \star}$ & $-0,024$ \\
\hline $\begin{array}{l}\text { dyplom potwierdzający kwalifikacje } \\
\text { uzyskany w } 2015 \text { r. (tak = 1) }\end{array}$ & $-0,008$ & 0,000 & $0,038^{*}$ & $-0,031^{\star \star \star}$ \\
\hline powtarzanie klasy (tak = 1) & 0,108 & $-0,068$ & $-0,139$ & 0,099 \\
\hline $\begin{array}{l}\text { posiadanie pracy przed } \\
\text { czerwcem } 2015 \text { r. }(\text { tak = 1) }\end{array}$ & $0,264^{\star \star \star}$ & $0,101^{\star *}$ & $-0,210^{\star \star \star}$ & $-0,155^{\star \star \star}$ \\
\hline $\begin{array}{l}\text { udział bezrobotnych w wieku 25-34 lata } \\
\text { w } 2014 \text { r. (+ } 1 \text { odchylenie standardowe) }\end{array}$ & $0,040^{\star \star \star}$ & $-0,023^{*}$ & $-0,057^{\star * *}$ & $0,041^{\star \star \star}$ \\
\hline
\end{tabular}

${ }^{\star} \mathrm{p}<0,05,{ }^{* \star} \mathrm{p}<0,01,{ }^{* \star *} \mathrm{p}<0,001$. Skróty obszarów kształcenia: AU - obszar

administracyjno-usługowy; BU - obszar budowlany; EE, MG - obszary elektroniczno-

-elektryczny i mechaniczno-górniczy; TG, R, M - obszary turystyczno-gastronomiczny,

rolny i medyczny.

Źródło: runda pilotażowa badania MLEZAMID.

\section{Forma zatrudnienia}

Dotychczas traktowaliśmy pracę jako jednorodną kategorię. W analizowanym badaniu pytano absolwentów nie tylko o początek i koniec zatrudnienia, ale też o jego podstawę prawną. Odpowiedzi respondentów wskazują, że najczęstszym sposobem wchodzenia na rynek pracy jest podjęcie zatrudnienia na podstawie umowy o pracę, poprzedzone krótszym lub dłuższym okresem nieaktywności zawodowej i edukacyjnej lub kształcenia się. Do rzadkości należały umowy cywilnoprawne. Wyjątkiem są też nieliczne osoby, które pracowały we własnym gospodarstwie rolnym lub podjęły własną działalność gospodarczą, 
które najczęściej miały tę formę pracy przez cały lub większość obserwowanego okresu.

Tabela 4. Odsetek absolwentów posiadających doświadczenie

różnych form aktywności zawodowej i średnia liczba miesięcy pozostawania

w aktywności zawodowej w trakcie 22 miesięcy po zakończeniu nauki

\begin{tabular}{|c|c|c|c|c|c|c|}
\hline & \multicolumn{2}{|c|}{$\begin{array}{c}\text { ogółem } \\
\text { (zasadnicze szkoły } \\
\text { zawodowe i technika) }\end{array}$} & \multicolumn{2}{|c|}{$\begin{array}{c}\text { zasadnicza } \\
\text { szkoła zawodowa }\end{array}$} & \multicolumn{2}{|c|}{ technikum } \\
\hline & $\begin{array}{c}\text { przynajmniej } \\
1 \text { miesiąc } \\
\text { w danym stanie } \\
\text { (\% absolwentów) }\end{array}$ & $\begin{array}{l}\text { średnia } \\
\text { liczba } \\
\text { miesięcy }\end{array}$ & $\begin{array}{c}\text { przynajmniej } \\
1 \text { miesiąc } \\
\text { w danym stanie } \\
\text { (\% absolwentów) }\end{array}$ & $\begin{array}{l}\text { średnia } \\
\text { liczba } \\
\text { miesięcy }\end{array}$ & $\begin{array}{c}\text { przynajmniej } \\
1 \text { miesiąc } \\
\text { w danym stanie } \\
\text { (\% absolwentów) }\end{array}$ & $\begin{array}{l}\text { średnia } \\
\text { liczba } \\
\text { miesięcy }\end{array}$ \\
\hline $\begin{array}{l}\text { nieaktywność } \\
\text { zawodowa }\end{array}$ & 75 & 8,4 & 74 & 6,9 & 76 & 9,1 \\
\hline umowa o pracę & 50 & 10,4 & 58 & 12,0 & 47 & 9,6 \\
\hline $\begin{array}{l}\text { umowa } \\
\text { cywilno-prawna }\end{array}$ & 9 & 1,2 & 7 & 1,1 & 10 & 1,3 \\
\hline $\begin{array}{l}\text { działalność } \\
\text { gospodarcza }\end{array}$ & 2 & 0,4 & 2 & 0,5 & 2 & 0,4 \\
\hline $\begin{array}{l}\text { praca we własnym } \\
\text { gospodarstwie }\end{array}$ & 3 & 0,6 & 2 & 0,3 & 4 & 0,8 \\
\hline $\begin{array}{l}\text { umowa } \\
\text { nieformalna }\end{array}$ & 4 & 0,5 & 5 & 0,7 & 4 & 0,5 \\
\hline $\begin{array}{l}\text { inna forma } \\
\text { zatrudnienia }\end{array}$ & 4 & 0,5 & 4 & 0,5 & 3 & 0,5 \\
\hline
\end{tabular}

Źródło: runda pilotażowa badania MLEZAMID.

Stabilność zatrudnienia na podstawie różnych podstaw zatrudnienia można badać w sposób empiryczny. Wartości prawdopodobieństw przejść między stanami (np. z nieaktywności do pracy) pozwalają wnioskować o najczęstszych zmianach stanu i stabilności każdego stanu (informacje o stabilności danego stanu). Najwyższe wartości wskaźników przejścia obserwujemy między:

$\rightarrow$ nieaktywnością a umową o pracę $(0,06)$,

$\rightarrow$ inną formą zatrudnienia a nieaktywnością $(0,05)$,

$\rightarrow$ zatrudnieniem na podstawie umowy cywilnoprawnej i nieaktywnością $(0,04)$,

$\rightarrow$ umową nieformalną a nieaktywnością $(0,04)$. 
W tabeli 5 pokazano wartości prawdopodobieństw przejść między różnymi formami zatrudnienia oszacowane dla typowego miesiąca z 22-miesięcznego okresu obserwacji. Niemal wszyscy (99\%) zatrudnieni na podstawie umowy o pracę kontynuują pracę na tej samej podstawie w kolejnym miesiącu. Przejścia z umowy o pracę do innego stanu doświadczyło ok. 9,5\% badanych absolwentów zasadniczych szkół zawodowych i podobny odsetek absolwentów techników. Przejście z pracy na umowę o pracę do innych stanów dotyczy przede wszystkim przejścia w nieaktywność zawodową. Wśród osób pracujących na podstawie umowy cywilnoprawnej $93 \%$ pozostaje w tej samej formie zatrudnienia w kolejnym miesiącu - pozostali częściej przestają pracować ( $4 \%$ przejść), niż uzyskują umowę o pracę ( $2 \%$ przejść). Bardzo podobnie wygląda sytuacja osób pracujących na czarno. Bardziej stabilne są prowadzenie działalności gospodarczej lub praca w gospodarstwie rolnym: w $99 \%$ przypadków osoby pracujące na tej podstawie robiły to także w kolejnym miesiącu.

Tabela 5. Prawdopodobieństwa przejść między formami zatrudnienia

w okresie 22 miesięcy po zakończeniu nauki

\begin{tabular}{|c|c|c|c|c|c|c|c|}
\hline & $\begin{array}{l}\text {->nieak- } \\
\text { tywność }\end{array}$ & $\begin{array}{c}\text {->umowa } \\
\text { o pracę }\end{array}$ & $\begin{array}{c}\text {->umowa } \\
\text { cywilno- } \\
\text {-prawna }\end{array}$ & $\begin{array}{l}\text {->dzia- } \\
\text { łalność } \\
\text { gospo- } \\
\text { darcza }\end{array}$ & $\begin{array}{c}\text {->gosp- } \\
\text { darstwo } \\
\text { rolne }\end{array}$ & $\begin{array}{c}\text {-> umowa } \\
\text { niefor- } \\
\text { malna }\end{array}$ & $\begin{array}{r}\text {->inna } \\
\text { forma }\end{array}$ \\
\hline nieaktywność-> & 0,92 & 0,06 & 0,01 & 0 & 0 & 0 & 0 \\
\hline umowa o pracę-> & 0,01 & 0,99 & 0 & 0 & 0 & 0 & 0 \\
\hline $\begin{array}{l}\text { umowa } \\
\text { cywilno-prawna-> }\end{array}$ & 0,04 & 0,02 & 0,93 & 0 & 0 & 0 & 0 \\
\hline $\begin{array}{l}\text { działalność } \\
\text { gospodarcza-> }\end{array}$ & 0,01 & 0 & 0 & 0,99 & 0 & 0 & 0 \\
\hline $\begin{array}{l}\text { gospodarstwo } \\
\text { rolne-> }\end{array}$ & 0 & 0,01 & 0 & 0 & 0,99 & 0 & 0 \\
\hline $\begin{array}{l}\text { umowa } \\
\text { nieformalna-> }\end{array}$ & 0,04 & 0,02 & 0,01 & 0 & 0 & 0,94 & 0 \\
\hline inna forma-> & 0,05 & 0,02 & 0 & 0 & 0 & 0 & 0,93 \\
\hline
\end{tabular}




\section{Epizody poszukiwania pracy i bezrobocia}

W pierwszych miesiącach po zakończeniu nauki poszukiwanie pracy deklarowało ok. $16 \%$ absolwentów. W kolejnych miesiącach odsetek ten zmniejszał się. Rok po zakończeniu nauki poszukiwanie pracy deklarowało zaledwie $8 \%$ absolwentów, a w 22. miesiącu - ok. $5 \%$ absolwentów. Prawie 1/3 poszukujących pracy jednocześnie uczyła się lub pracowała.

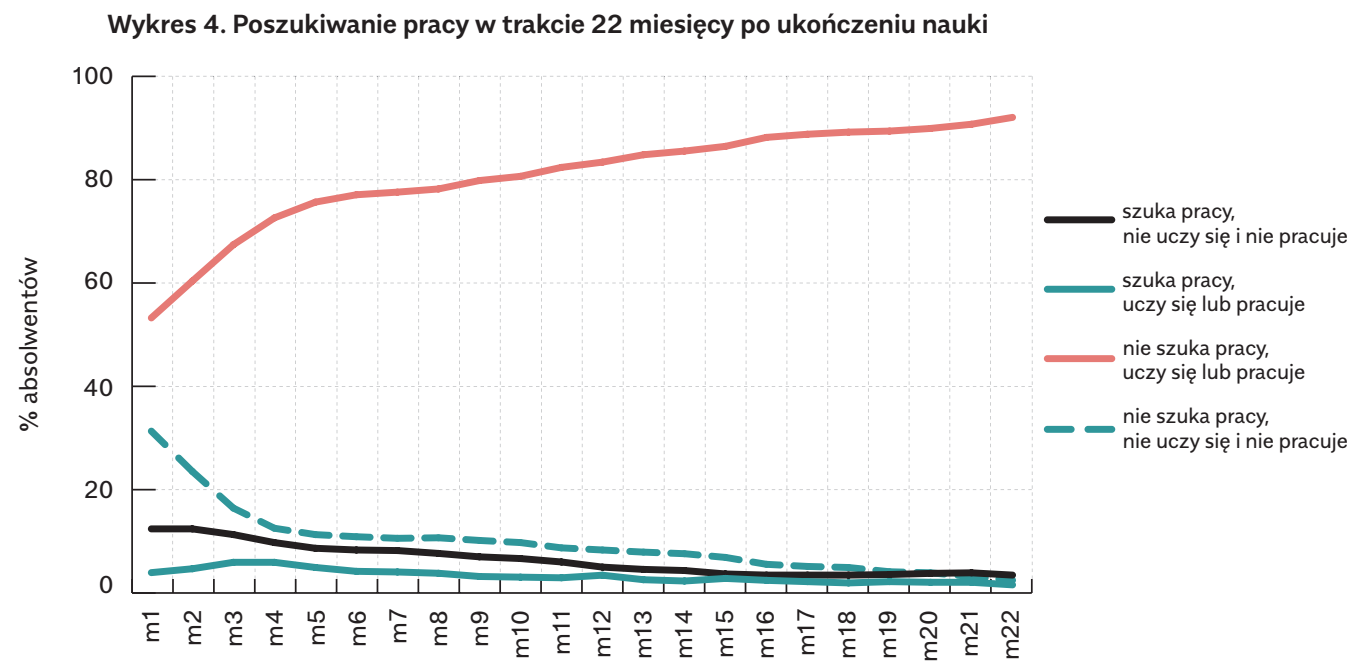

Źródło: runda pilotażowa badania MLEZAMID.

W analizowanym okresie ok. $25 \%$ absolwentów zasadniczych szkół zawodowych i $19 \%$ absolwentów techników przynajmniej raz zarejestrowało się w urzędzie pracy jako bezrobotny - wśród osób nieaktywnych był to co drugi absolwent. Odsetek ten był też relatywnie wysoki wśród absolwentów zasadniczych szkół zawodowych, którzy kontynuują naukę. Pod tym względem widoczne są duże różnice między zasadniczymi szkołami zawodowymi a technikami. Absolwenci techników kontynuujący naukę doświadczali bezrobocia najrzadziej. Większość osób, które rejestrowały się jako bezrobotni, robiła to tuż po zakończeniu nauki. Najczęściej wskazywanymi motywacjami do wizyty w urzędzie pracy były potrzeba uzyskania ubezpieczenia zdrowotnego i możliwość skorzystania z pośrednictwa pracy. 
Tabela 6. Odsetek badanych mających doświadczenia bezrobocia w ramach poszczególnych grup respondentów w zależności od rodzaju ukończonej szkoły

\begin{tabular}{l|c|c} 
& $\begin{array}{c}\text { zasadnicza } \\
\text { szkoła zawodowa }\end{array}$ & technikum \\
\hline ogółem (wszyscy absolwenci) & 24,9 & 19,0 \\
\hline pracujący & 14,1 & 18,7 \\
\hline łączący pracę z nauką & 22,0 & 12,6 \\
\hline uczący się & 35,2 & 4,6 \\
\hline nieaktywni & 51,8 & 48,6 \\
\hline
\end{tabular}

Źródło: runda pilotażowa badania MLEZAMID.

Wśród absolwentów zasadniczych szkół zawodowych nie ma różnic między obszarami kształcenia. Z uwzględnionych predyktorów jedynie stopa bezrobocia osób młodych oraz posiadanie pracy przed ukończeniem nauki zmniejszają prawdopodobieństwo doświadczenia bezrobocia, a wykorzystany model jedynie w niewielkim stopniu wyjaśnia zróżnicowanie absolwentów pod tym względem (pseudo R2 $=0,04$ ). Podobny obraz wpływu poszczególnych zmiennych daje analiza danych dotyczących absolwentów techników (pseudo R2 $=0,06$ ). W urzędach pracy częściej rejestrują się kobiety. Wśród absolwentów techników prawdopodobieństwo doświadczenia bezrobocia rejestrowanego jest mniejsze u osób, które znalazły pracę przed zakończeniem nauki lub uzyskały dyplom potwierdzający kwalifikacje. Siła i kierunek efektów tych zmiennych są podobne do tych zaobserwowanych w zasadniczych szkołach zawodowych. W przypadku absolwentów techników widoczny jest niewielki wpływ obszaru kształcenia na prawdopodobieństwo doświadczenia bezrobocia. Zapewne efekty te byłyby bardziej wyraźne, gdyby badana liczba absolwentów była większa, a zamiast obszarów kształcenia wykorzystano by mniej zróżnicowane, pod względem specyfiki wchodzących weń zawodów, kategorie (np. branże zawodowe). 
Tabela 7. Predyktory doświadczenia przynajmniej jednego miesiąca bezrobocia rejestrowanego wśród absolwentów zasadniczych szkół zawodowych i techników (wyniki regresji logistycznych przeprowadzonych osobno dla zasadniczych szkół zawodowych i techników - średnie efekty krańcowe)

\begin{tabular}{l|c|c} 
& $\begin{array}{c}\text { zasadnicza } \\
\text { szkoła zawodowa }\end{array}$ & technikum \\
\hline płeć kobieta (=1) & 0,054 & $0,075^{\star \star}$ \\
\hline obszar kształcenia & & \\
\hline BU vs AU & $-0,037$ & 0,135 \\
\hline EE, MG vs AU & $-0,021$ & $-0,008$ \\
\hline TG, R, M vs AU & $-0,007$ & $-0,005$ \\
\hline EE, MG vs BU & 0,016 & $-0,143^{\star}$ \\
\hline TG, R, M vs BU & 0,029 & $-0,14^{*}$ \\
\hline TG, R, M vs EE, MG & 0,013 & 0,003 \\
\hline $\begin{array}{l}\text { dyplom potwierdzający kwalifikacje } \\
\text { uzyskany w 2015 r. (tak = 1) }\end{array}$ & $-0,064$ & $-0,078^{\star}$ \\
\hline $\begin{array}{l}\text { posiadanie pracy } \\
\text { przed czerwcem 2015 r. tak (= 1) }\end{array}$ & $-0,141^{\star \star}$ & $-0,121^{\star \star *}$ \\
\hline $\begin{array}{l}\text { udział bezrobotnych w wieku 25-34 lata } \\
\text { w 2014 r. (+1 odchylenie standardowe) tak (= 1) }\end{array}$ & $0,057^{\star *}$ & $0,066^{\star \star *}$ \\
\hline
\end{tabular}

${ }^{*} p<0,05,{ }^{* \star} p<0,01,{ }^{\star * *} p<0,001$. Skróty obszarów kształcenia: AU - obszar administracyjno-usługowy; BU - obszar budowlany; EE, MG - obszary elektroniczno-elektryczny i mechaniczno-górniczy; TG, R, M - obszary turystyczno-gastronomiczny, rolny i medyczny.

Źródło: runda pilotażowa badania MLEZAMID.

\section{Prace dorywcze}

Przedstawione powyżej analizy pokazują, że posiadanie pracy przed zakończeniem nauki istotnie zmniejsza prawdopodobieństwo trafienia do grupy osób nieaktywnych, a zwiększa szanse łączenia przez absolwentów pracy z nauką. W tym kontekście znaczenia nabierają wszelkie doświadczenia zawodowe, również te, które trwały zbyt krótko, aby respondenci odnotowali je jako epizody zatrudnienia.

Dlatego ankietowanych absolwentów zapytano o podejmowanie prac dorywczych i sezonowych - z założenia nieregularnych i trwających nie dłużej niż kilka - kilkanaście dni, które badani podejmowali 
od lipca 2015 r. Jak się okazało, prac dorywczych w badanym okresie podejmowało się zaledwie $23 \%$ ogółu badanych. Wyraźnie częściej $(35 \%)$ w ten sposób pracowali absolwenci techników, którzy kontynuują naukę w szkołach policealnych lub na studiach.

Tabela 8. Odsetek osób podejmujących prace dorywcze w poszczególnych

grupach absolwentów szkół kształcących zawodowo

\begin{tabular}{l|c|c|}
\multicolumn{1}{c|}{ kategoria } & $\%$ & N \\
\hline \begin{tabular}{l|l|} 
absolwenci zasadniczej szkoły zawodowej \\
aktywni zawodowo i nieaktywni edukacyjnie
\end{tabular} & 21 & 548 \\
\hline absolwenci techników aktywni zawodowo i nieaktywni edukacyjnie & 20 & 852 \\
\hline absolwenci asadniczej szkoły zawodowej łączący pracę z nauką & 24 & 208 \\
\hline absolwenci techników łączący pracę z nauką & 35 & 415
\end{tabular}

Źródło: runda pilotażowa badania MLEZAMID.

Średnio, badani wskazywali na trzy takie sytuacje $(N=465$, std $=5)$, a całkowity czas wykonywania prac dorywczych w badanym okresie oszacowano na średnio 15 tygodni $(\mathrm{N}=367$, std $=20)$. Niemniej zarówno w przypadku liczby, jak i całkowitego okresu prac dorywczych odpowiedzi absolwentów były bardzo zróżnicowane, a podawane szacunki nierzadko mało wiarygodne. Branże, w których absolwenci pracowali dorywczo, pozostają w pewnym stopniu zgodne z ich obszarami kształcenia. W szczególności dotyczy to absolwentów kierunków budowlanych, turystyczno-gastronomicznych i administracyjno-usługowych, którzy najczęściej pracowali dorywczo w zawodach odpowiadających ich wyuczonym specjalnościom - budownictwie, gastronomii i handlu. Odsetek absolwentów podejmujących prace dorywcze w rolnictwie pozostaje podobny (ok. 21\% wśród osób podejmujących prace dorywcze), niezależnie od obszaru wykształcenia respondenta. Prace dorywcze w rolnictwie najwyraźniej wiążą się głównie z pomocą w rodzinnym gospodarstwie rolnym. Są również wyraźnie częściej podejmowane przez osoby zamieszkujące $w$ powiatach o bardziej rolniczym charakterze: w powiatach o udziale użytków rolnych poniżej $48 \%$ prace dorywcze $w$ rolnictwie wykonywał co dziesiąty badany, a w powiatach 
o udziale użytków rolnych przekraczającym $73 \%$ było to $48 \%$ badanych absolwentów.

Znaczna część prac dorywczych wykonywanych przez absolwentów ma charakter nieformalny. Niemniej absolwenci techników i ZSZ, którzy kontynuują naukę, częściej niż pozostali podejmowali prace dorywcze, które wiązały się z podpisaniem umowy.

Wykres 5. Prace dorywcze i podstawa zatrudnienia - porównanie doświadczeń absolwentów techników i zasadniczych szkół zawodowych

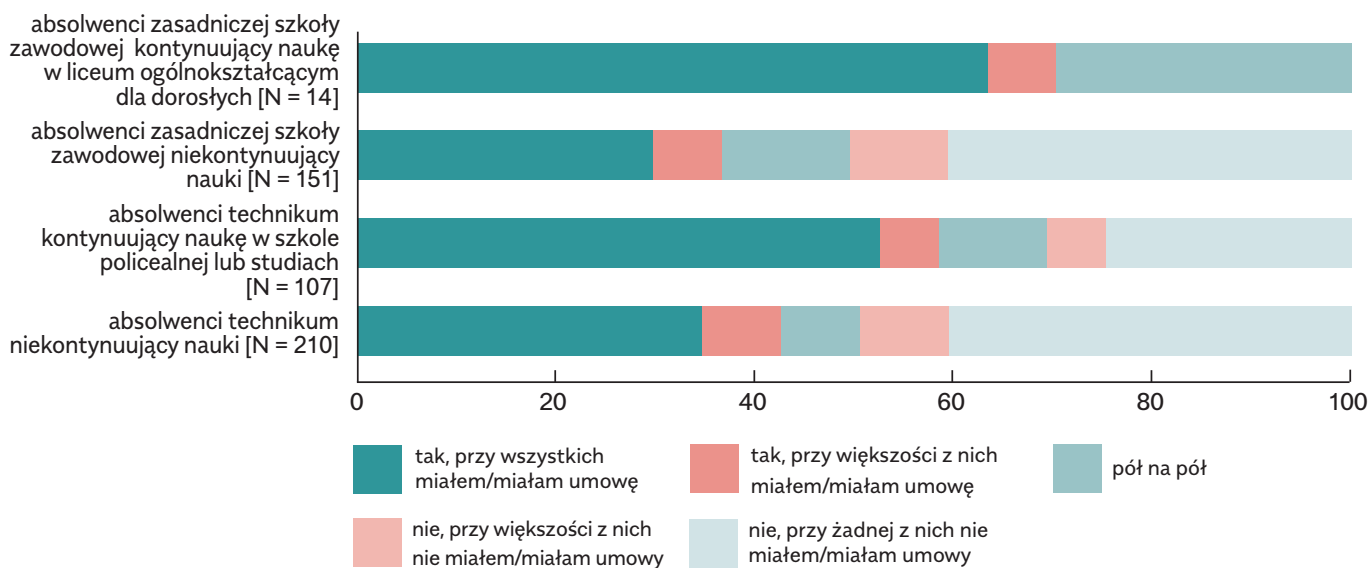

Źródło: runda pilotażowa badania MLEZAMID.

\section{Pierwsza praca absolwentów szkół kształcących zawodowo - ogólna charakterystyka}

Wiele badań wskazuje, że pierwsza praca absolwentów ma duże znaczenie dla przebiegu ich dalszej kariery zawodowej. W przypadku badanej grupy absolwentów szkół kształcących zawodowo pierwsza praca to zarazem najczęściej ich dotychczas jedyne doświadczenie zawodowe. 22 miesiące po ukończeniu nauki w szkole zawodowej pracę podjętą w pierwszym miejscu zatrudnienia kontynuowało aż $62 \%$ badanych absolwentów.

Wśród absolwentów, których pierwsza praca zakończyła się wcześniej niż 22 miesiące po ukończeniu nauki, zdecydowana większość (74\%) odeszła z własnej inicjatywy. Zakończenie pracy z powodu nie- 
przedłużenia umowy dotyczyło $22 \%$ absolwentów, a likwidacja stanowiska ok. $4 \% \mathrm{z}$ nich.

Zdecydowana większość ankietowanych absolwentów znalazła pierwszą pracę najwyżej po miesiącu poszukiwań, w tym większość deklarowała, że zrobiła to od ręki.

Wykres 6. Okres poszukiwania pierwszej pracy w podziale na kategorie absolwentów

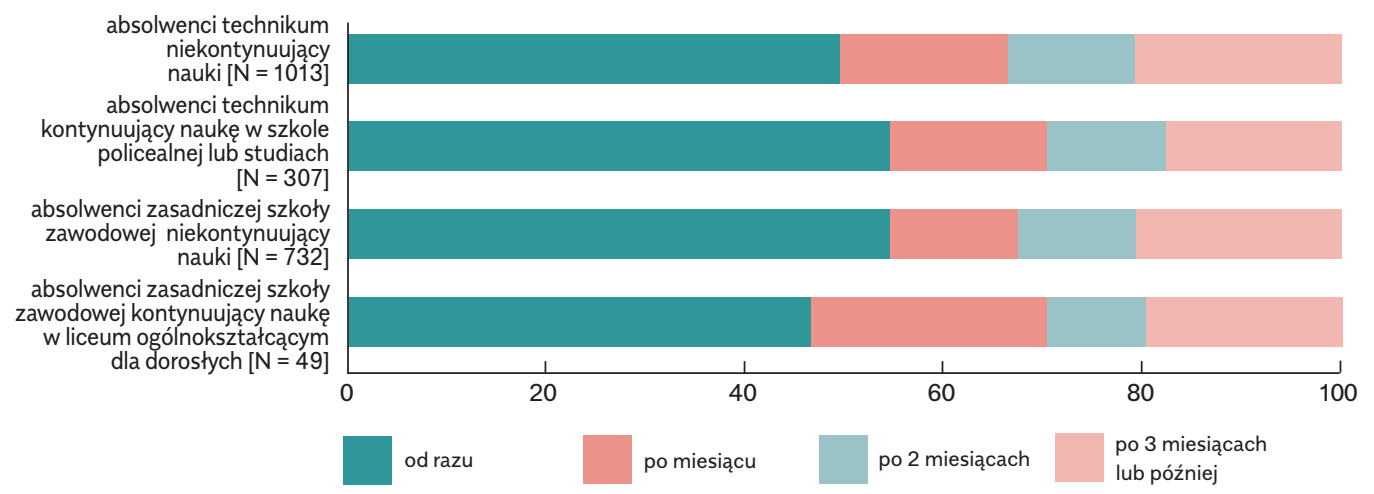

Źródło: runda pilotażowa badania MLEZAMID.

Absolwenci, którzy kształcili się w zawodach z obszarów elektroniczno-elektrycznego i mechaniczno-górniczego, stosunkowo najczęściej (ok. 56\%) znajdowali zatrudnienie od ręki. Nieco większe problemy ze znalezieniem pierwszej pracy mieli absolwenci kierunków administracyjno-usługowych - ponad połowa (55\%) z nich szukała pierwszej pracy przez co najmniej miesiąc.

Część z respondentów pracowała już w trakcie kończenia nauki w szkole ponadgimnazjalnej, w której prowadzono badanie w czerwcu 2015 r. Dynamika znajdowania pracy jest największa w pierwszych pięciu miesiącach po zakończeniu nauki, zwłaszcza wśród absolwentów zasadniczych szkół zawodowych i techników, którzy nie kontynuują edukacji. Bardziej rozłożone w czasie jest zdobywanie pierwszych doświadczeń zawodowych wśród absolwentów kontynuujących kształcenie. 
Wykres 7. Moment rozpoczęcia pracy, w której absolwenci pracowali w czerwcu 2015 r. lub którą podjęli po czerwcu 2015 r.

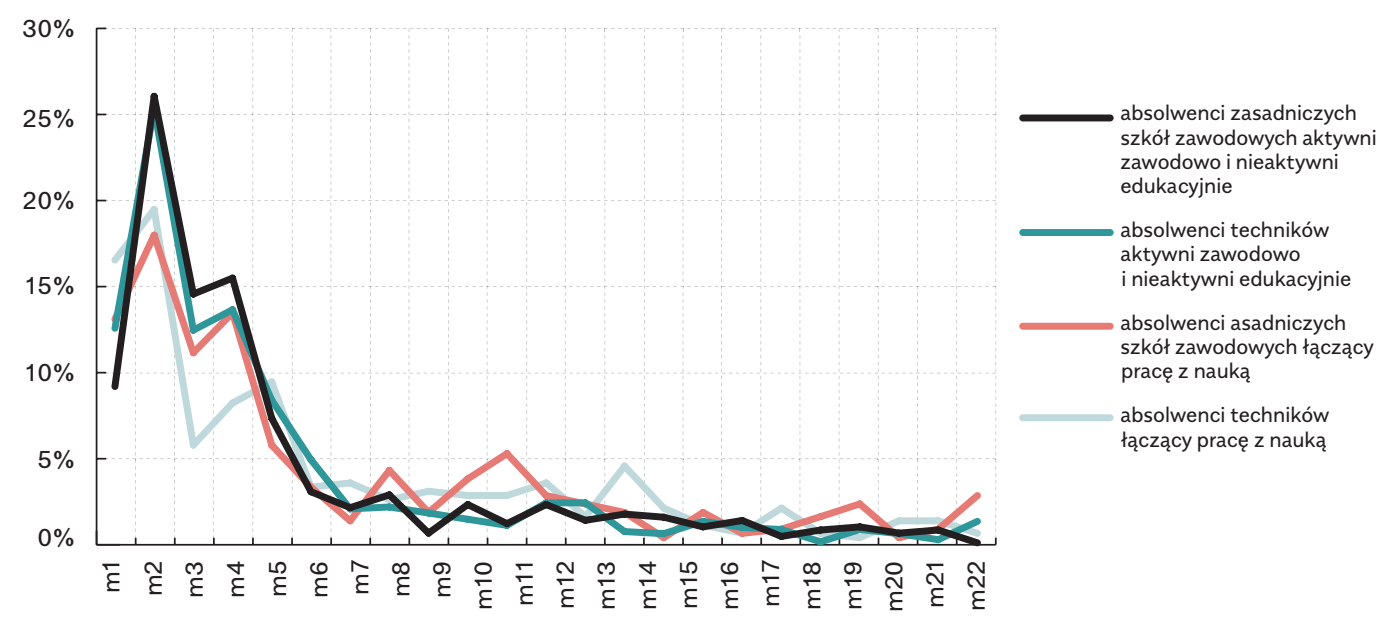

Źródło: runda pilotażowa badania MLEZAMID.

Jak wspomniano wcześniej, większość absolwentów rozpoczynała karierę zawodową na podstawie umowy o pracę. Najwyższy odsetek rozpoczynających pracę zawodową na podstawie umów o pracę zarejestrowano wśród absolwentów ZSZ, którzy są nieaktywni edukacyjnie. W tej grupie zanotowano również wysoki udział pracujących na czarno (8\%). Z kolei w przypadku osób kontynuujących naukę, zarówno absolwentów techników, jak i ZSZ, częstsza jest praktyka zatrudniania się na podstawie umów cywilnoprawnych. Obserwacja ta nie dziwi, zważywszy na to, że w przypadku osób do 26. roku życia, które wciąż się uczą, pracodawca nie ma obowiązku odprowadzania składek społecznych i zdrowotnych od umowy zlecenia/o dzieło, co dla zatrudnionych może wiązać się z wyższymi zarobkami netto. 
Wykres 8. Podstawa zatrudnienia w pierwszej pracy w podziale na kategorie absolwentów

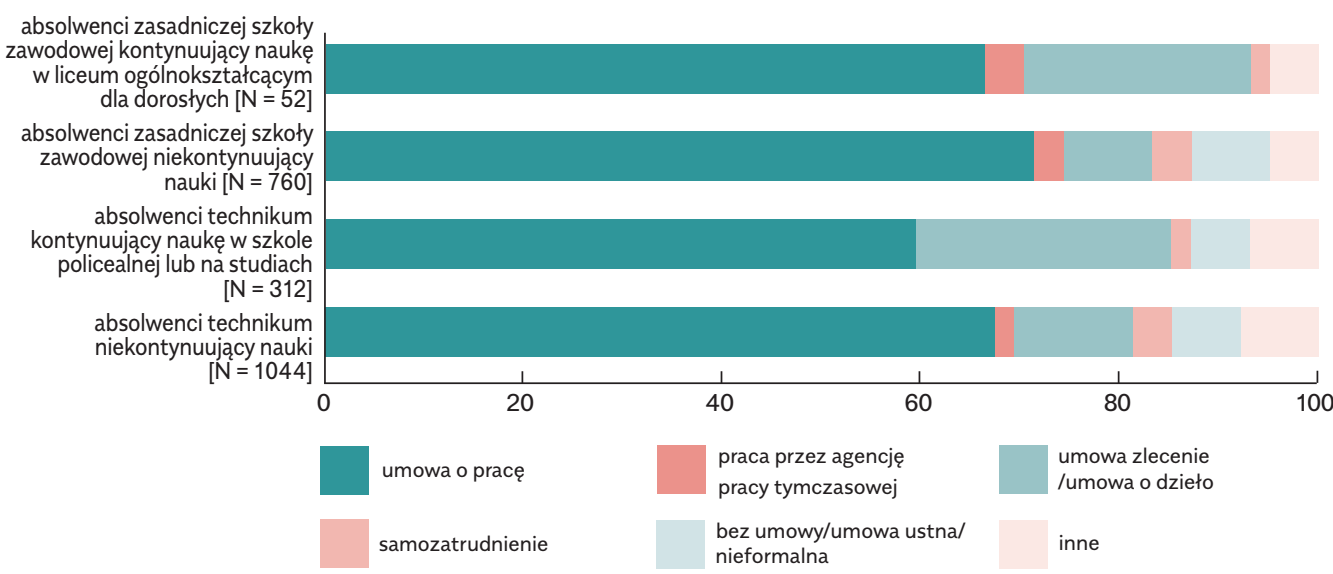

Źródło: runda pilotażowa badania MLEZAMID.

Przeciętne zarobki badanych absolwentów w pierwszej pracy oscylowały wokół 1850 zł (mediana) i były nieco wyższe w przypadku osób, które już nie kontynuowały nauki. Zakres wysokości zarobków absolwentów techników i ZSZ, w szczególności osób, które zakończyły już edukację, charakteryzuje się dużą rozpiętością - od kilkuset do nawet 12 tys. $z \nmid$. 


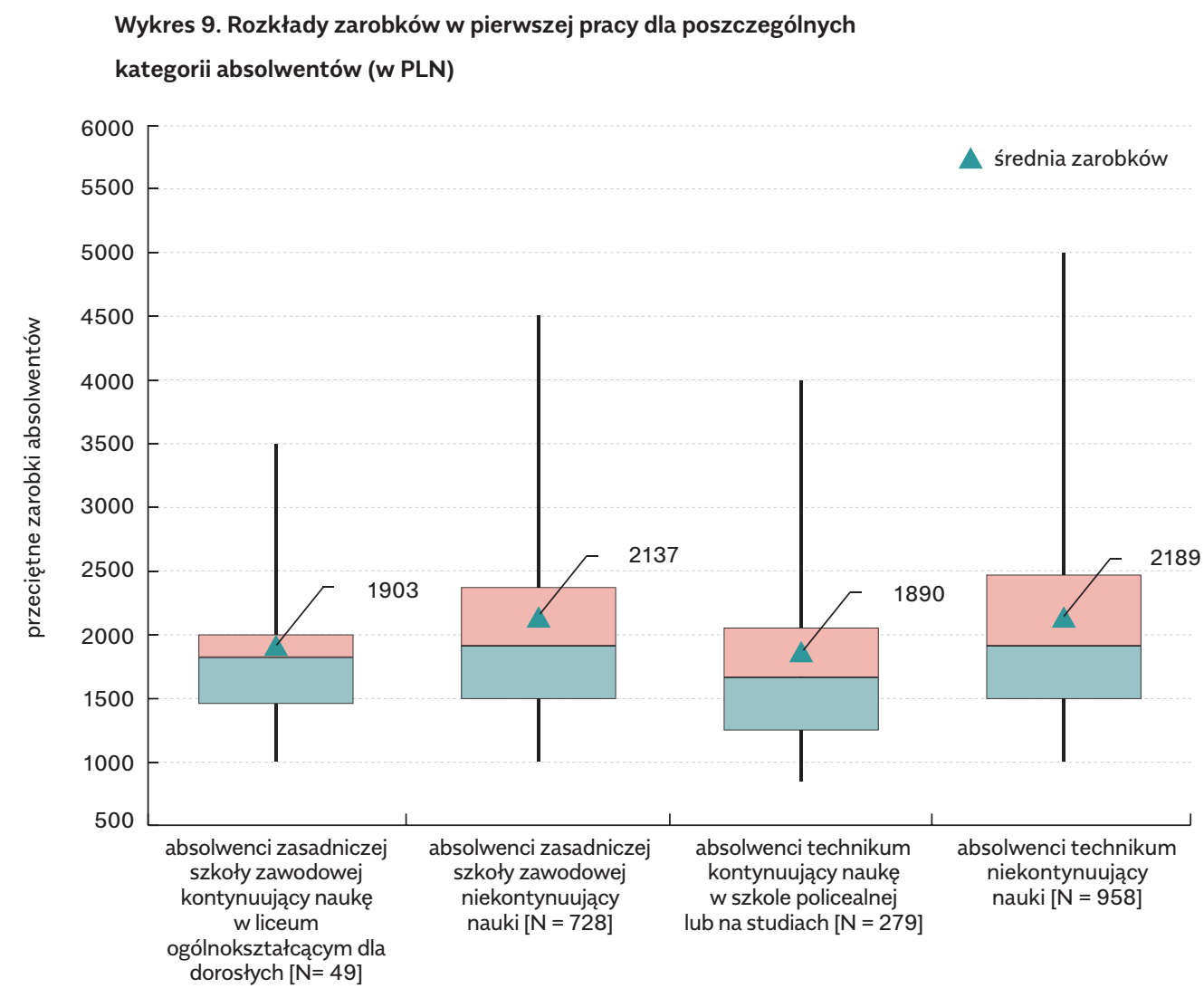

Źródło: runda pilotażowa badania MLEZAMID.

Wykres pudełkowy przedstawia 5 i 95 percentyl (oznaczone za pomocą wąsów) zarobków w danej kategorii. Górna krawędź pudełka reprezentuje trzeci kwartyl, dolna krawędź pierwszy kwartyl, a linia przebiegająca wewnątrz pudełka - medianę. Średnie zarobki oznaczono za pomocą punktu wraz z etykietą wartości.

Różnice w zarobkach w pierwszej pracy absolwentów zdecydowanie wyraźniej zaznaczają się w przekroju obszarów, w których kształcili się respondenci. Na najwyższe zarobki mogli liczyć ci, którzy kształcili się w zawodach z branży budowlanej - w tej kategorii wyraźne jest również bardzo duże zróżnicowanie wysokości wynagrodzeń. 
Wykres 10. Rozkłady zarobków w pierwszej pracy dla kategorii absolwentów

wyróżnionych ze względu na obszary kształcenia (w PLN)

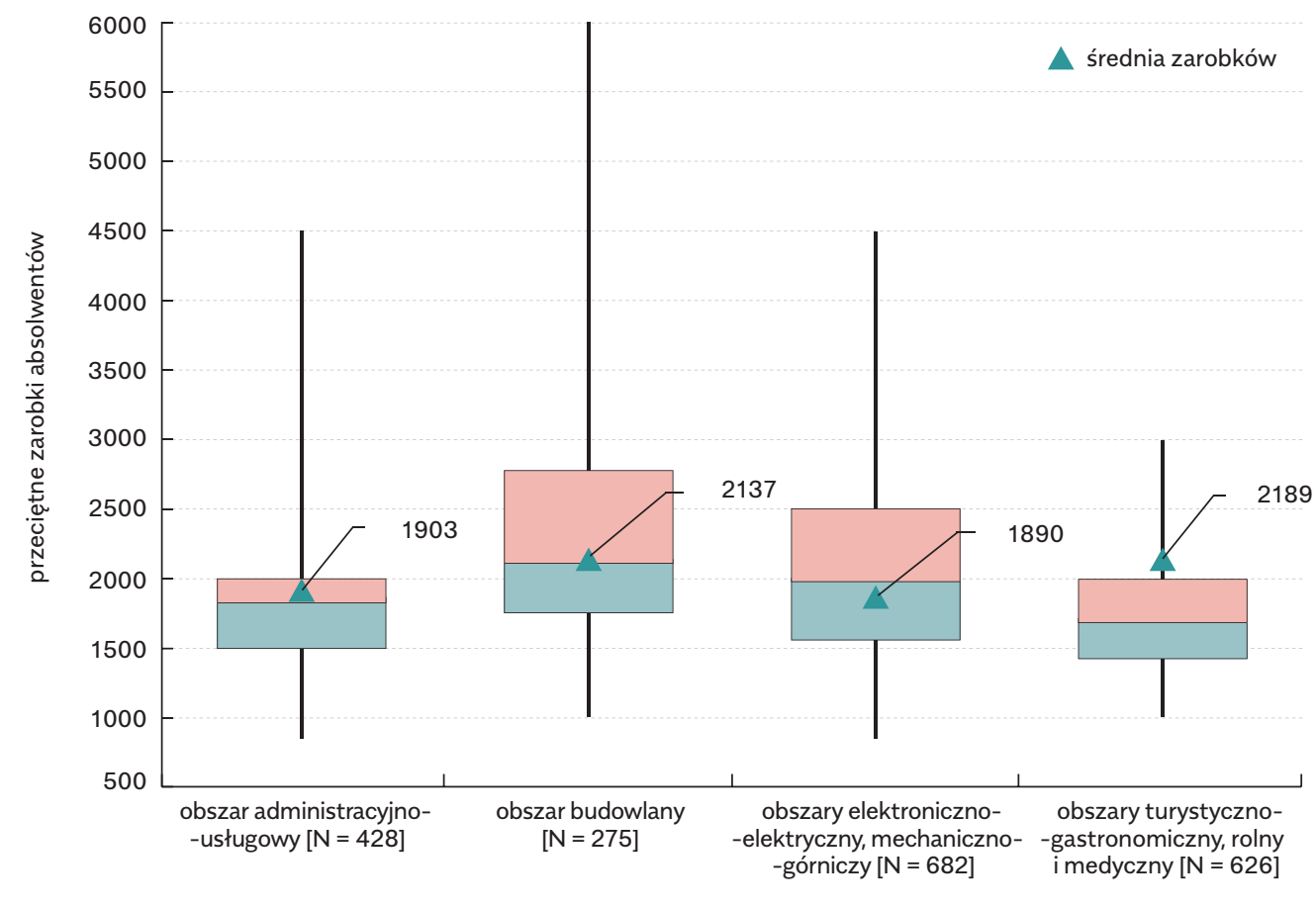

Źródło: runda pilotażowa badania MLEZAMID.

Wykres pudełkowy przedstawia 5 i 95 percentyl (oznaczone za pomocą wąsów) zarobków w danej kategorii. Górna krawędź pudełka reprezentuje trzeci kwartyl, dolna krawędź pierwszy kwartyl, a linia przebiegająca wewnątrz pudełka - medianę. Średnie zarobki oznaczono za pomocą punktu wraz z etykietą wartości.

Nieco ponad $70 \%$ absolwentów dojeżdżało do swojej pierwszej pracy $z$ domu rodzinnego, niemal $21 \%$ nie mieszkało już w tym czasie z rodzicami. Około $8 \%$ badanych rozpoczęło swoją karierę zawodową za granicą. Najczęściej byli to absolwenci kierunków budowlanych (16\% osób podejmujących pierwszą pracę za granicą). Większość absolwentów podejmujących pierwszą pracę za granicą decydowała się na wyjazd do Niemiec, Holandii lub Belgii. Wśród absolwentów techników 
najbardziej popularne były wyjazdy do Wielkiej Brytanii, Irlandii, Belgii i Holandii. Z kolei absolwenci ZSZ wyraźnie częściej wyjeżdżali do pracy do Niemiec.

Wykres 11. Kierunki wyjazdów osób podejmujących pierwszą pracę za granicą

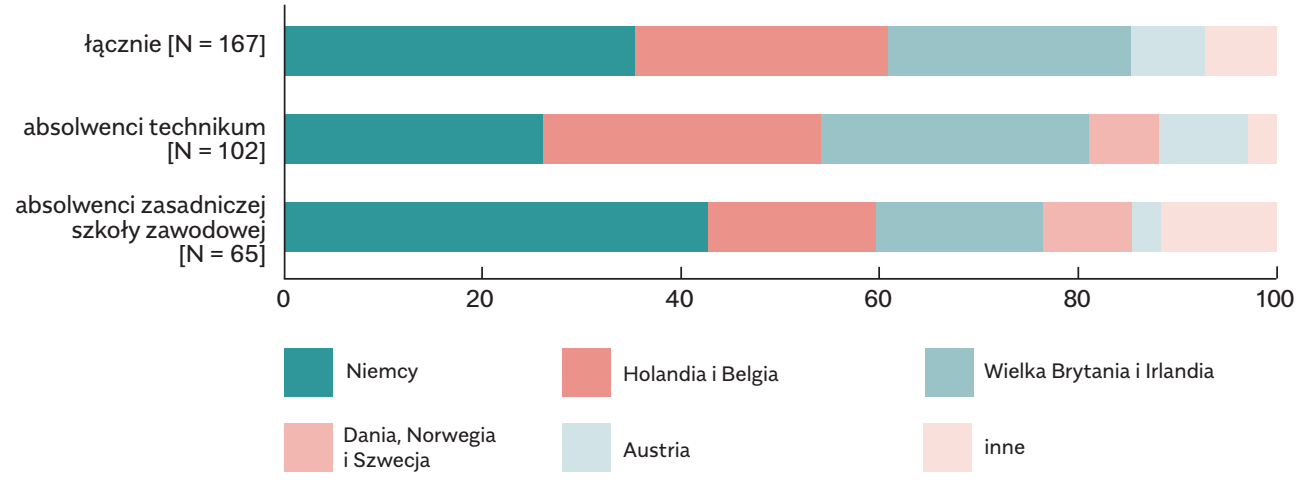

Źródło: BKL, badania pracodawców 2017.

\section{Zgodność pierwszej pracy z wykształceniem} i satysfakcja z zatrudnienia

Zrealizowane badanie sondażowe dostarczyło również informacji o zgodności pierwszej pracy absolwentów z ich wykształceniem. Spośród wszystkich badanych, którzy mieli jakiekolwiek doświadczenia zawodowe, $37 \%$ podjęło pracę w zawodzie zgodnym z kwalifikacjami uzyskanymi w szkole. Odsetek ten jest wyraźnie wyższy w przypadku grupy absolwentów zasadniczych szkół zawodowych, którzy zakończyli już edukację - wyniósł $48 \%$. Jeśli w tej grupie uwzględnić osoby, które stwierdziły, że chociaż ich praca nie jest zgodna z zawodem wyuczonym w szkole, to jednak wymaga podobnych kwalifikacji - to odsetek absolwentów ZSZ pracujących w zawodzie wzrasta do 57\%. 
Wykres 12. Zgodność pierwszej pracy z wykształceniem

w podziale na kategorie absolwentów

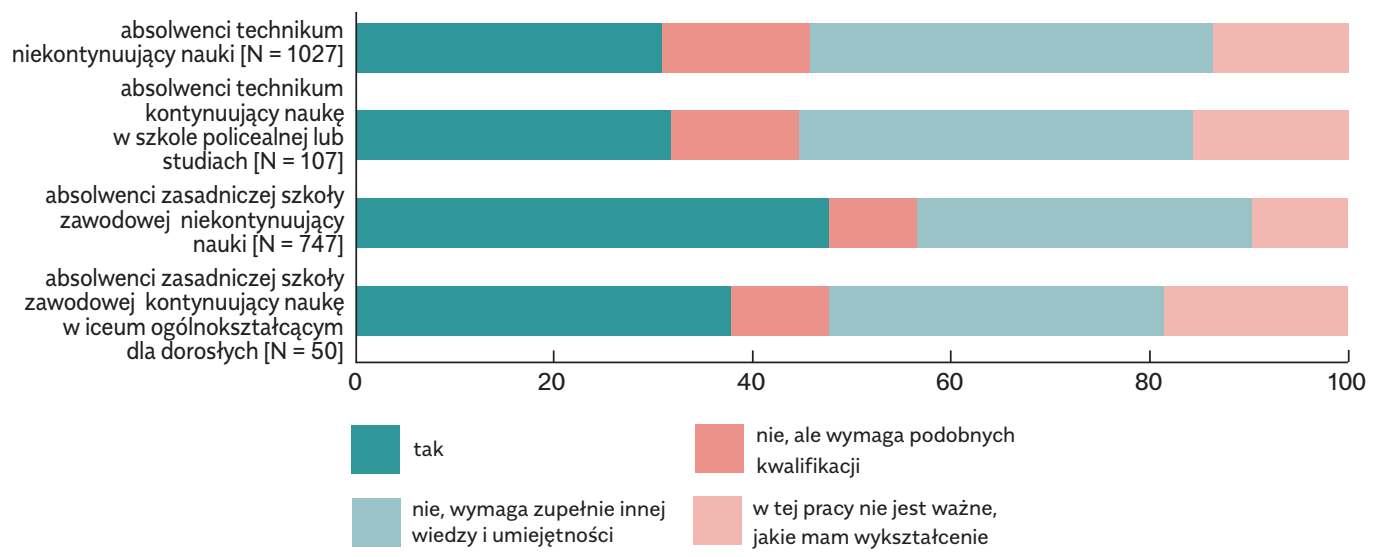

Źródło: runda pilotażowa badania MLEZAMID.

Absolwenci ZSZ, którzy kontynuują naukę w szkołach dla dorosłych, nieco rzadziej deklarowali pełną zgodność pracy z wyuczonym zawodem $(38 \%)$ - jednocześnie w przypadku tej kategorii zwraca uwagę spory odsetek osób, które odpowiedziały, że w ich pracy nie jest ważne, jakie mają wykształcenie.

Sytuacja ta przedstawia się zgoła inaczej w przypadku absolwentów techników. Odsetek pracujących w wyuczonym zawodzie jest wśród nich wyraźnie niższy niż w przypadku uczniów kończących zasadnicze szkoły zawodowe. Dotyczy to przede wszystkim udziału osób deklarujących pełną zgodność zawodu wykonywanego z zawodem wyuczonym (nieco poniżej 1/3 badanych). Jeżeli uwzględnimy osoby, których pierwsza praca wymagała kwalifikacji podobnych do tych zdobytych w szkole, odsetek absolwentów pracujących w zawodzie zbliża się do poziomu zaobserwowanego w przypadku absolwentów ZSZ (45\%). Co ciekawe, wśród absolwentów techników zasadniczo nie widać istotnych różnic między osobami kontynuującymi edukację i jej niekontynuującymi. Niezależnie od sytuacji zawodowej aż $40 \%$ absolwentów techników uzyskuje pierwszą pracę, która wymaga zupełnie innych umiejętności i wiedzy niż te zdobyte w szkole. Interesująco przedsta- 
wia się zgodność pracy z wyuczonym zawodem ze względu na obszar kształcenia absolwentów.

Wykres 13. Zgodność pierwszej pracy z wykształceniem

w podziale na kategorie absolwentów

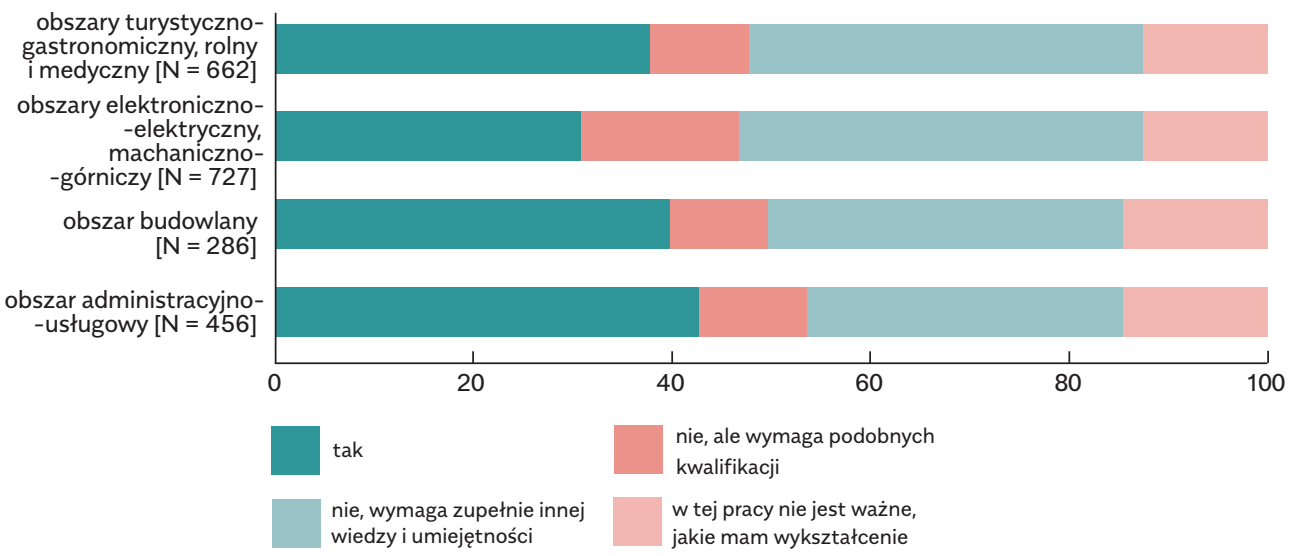

Źródło: runda pilotażowa badania MLEZAMID.

Zaskakuje fakt, że tylko 1/3 absolwentów, którzy uzyskali kwalifikacje w obszarach elektroniczno-elektrycznym i mechaniczno-górniczym, podejmuje pierwszą pracę dokładnie odpowiadającą wyuczonemu zawodowi. Niemniej, jeśli uwzględnić osoby, których praca zasadniczo wymagała kwalifikacji i umiejętności podobnych do tych wyuczonych w szkole (16\%), okazuje się, że absolwenci tych kierunków przestają tak wyraźnie odstawać na tle pozostałych kategorii wyróżnionych ze względu na obszar kształcenia. Wysoki poziom dopasowania uzyskanego wykształcenia zawodowego do charakteru podejmowanej pracy charakteryzuje natomiast absolwentów kierunków z obszaru budowlanego (40\%) i administracyjno-usługowego (43\%). Są to jednak zarazem dziedziny, w których najwyższy odsetek pracujących absolwentów zadeklarował, że w ich pracy to, jakie mają wykształcenie, nie ma znaczenia.

Różnice między absolwentami można również analizować w podziale ze względu na zawody. W tym kontekście uwagę zwracają przede wszystkim różnice w odsetku osób, które twierdzą, że posiadane przez 
nich wykształcenie nie ma znaczenia w wykonywanej przez nich pracy. Takich osób jest niewiele w zawodach gastronomicznych i relatywnie dużo wśród techników hotelarstwa czy techników ekonomistów. Opinia badanych na temat wpływu uzyskanego wykształcenia na wykonywaną pracę może świadczyć o niedopasowaniu popytu i podaży na rynku pracy. Aż połowa techników informatyków wybrała odpowiedź, że wykonywana przez nich praca wymaga zupełnie innej wiedzy i umiejętności niż te zdobyte w szkole - najczęściej dotyczy to wykonywania prac technicznych niezwiązanych bezpośrednio z informatyką.

Wykres 14. Zgodność pierwszej pracy z wykształceniem w podziale na wybrane zawody

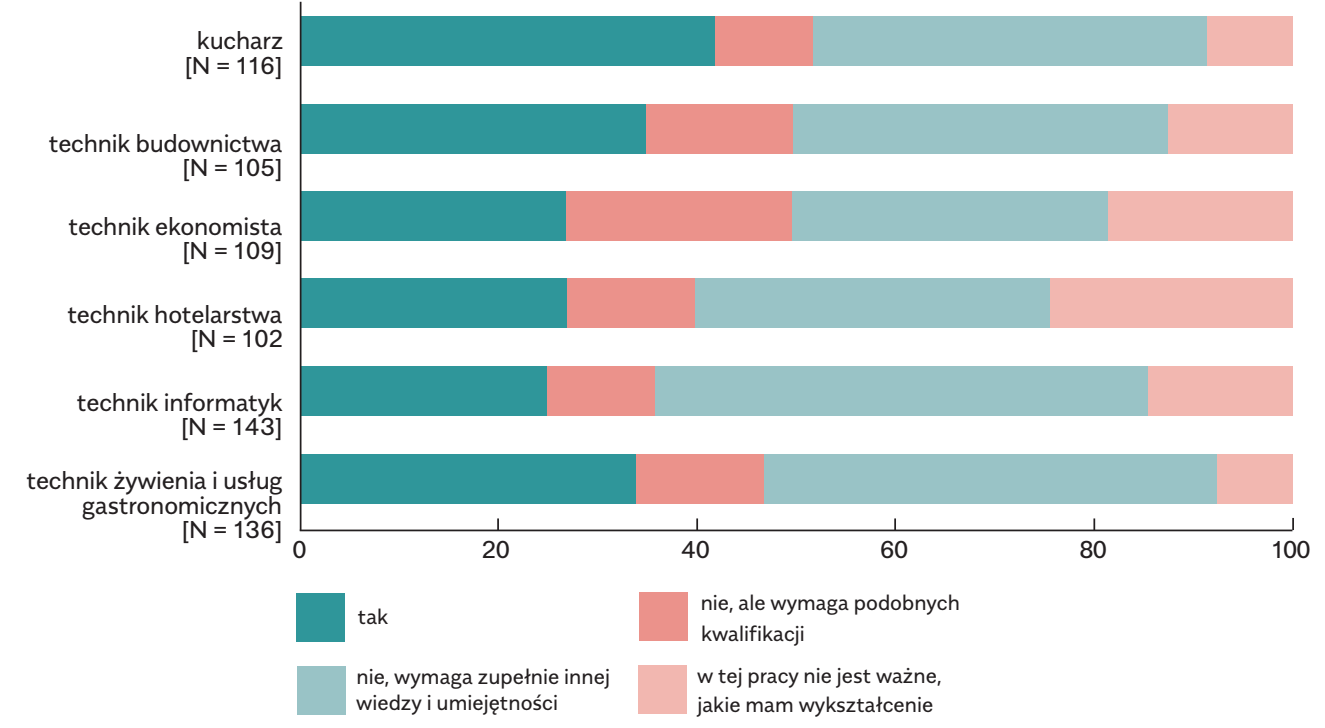

Źródło: runda pilotażowa badania MLEZAMID.

Ankietowanych absolwentów poproszono o dokonanie oceny ich pierwszej pracy pod względem kilku aspektów. Posługując się sześciostopniową szkolną skalą (od 1 - niedostateczny - do 6 - celujący), oceniali oni, na ile praca odpowiada ich oczekiwaniom - ze względu na poziom zarobków, atmosferę w pracy, ilość obowiązków, możliwości awansu, elastyczność godzin pracy i możliwości rozwoju kariery. Zebrane oceny okazały się raczej krytyczne - badani najczęściej wy- 
bierali odpowiedzi będące środkiem skali: średnia ocena stopnia, w jakim praca odpowiada ogólnym oczekiwaniom absolwentów, wyniosła $3,5(N=1550$, std $=1,13)$. Co ciekawe, najlepiej swoją pracę oceniali absolwenci techników, którzy kontynuują naukę - dotyczy to zarówno ogólnego spełnienia ich oczekiwań wobec pracodawcy, jak i możliwości rozwoju kariery i awansu, atmosfery w pracy, ilości obowiązków i wysokości zarobków. Wbrew pozorom oceny absolwentów ZSZ i techników, którzy ukończyli już naukę, były do siebie bardzo zbliżone - absolwenci ZSZ oceniali lepiej jedynie elastyczność godzin pracy.

Wykres 15. Oceny pierwszej pracy według kategorii absolwentów

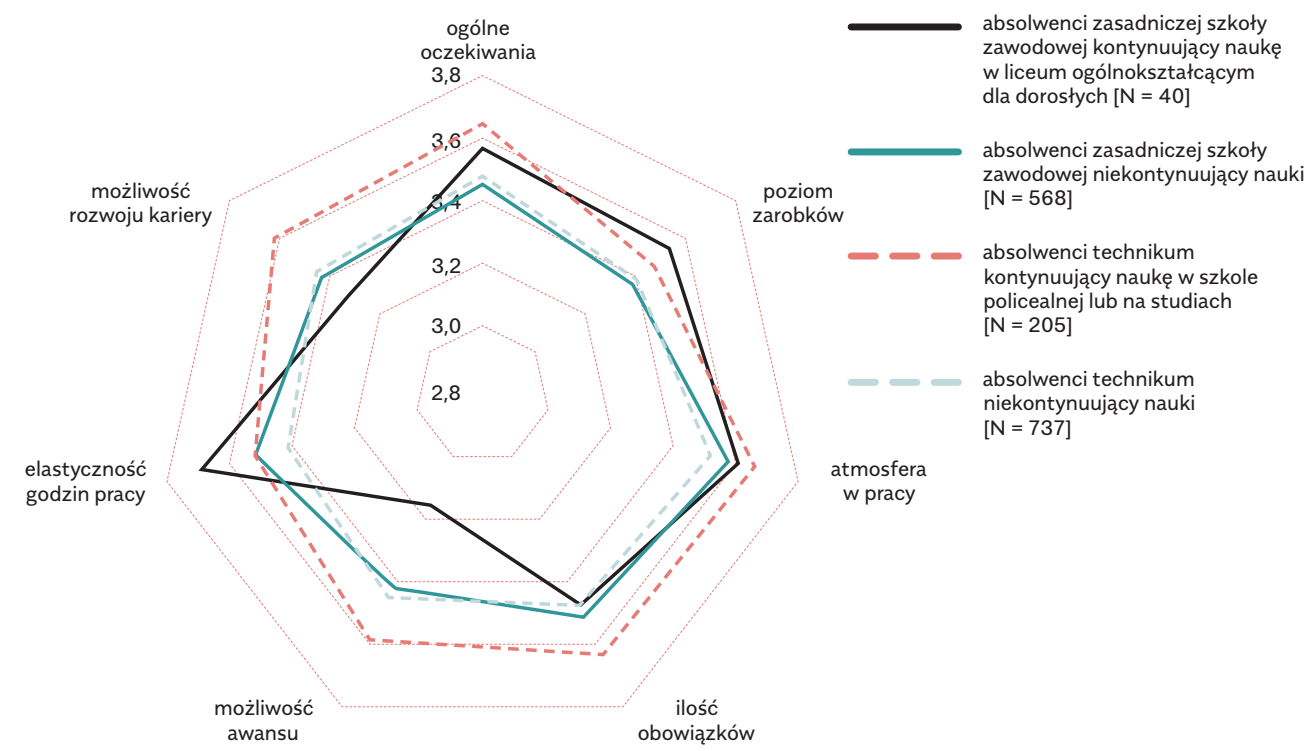

Źródło: runda pilotażowa badania MLEZAMID.

Wykres radarowy przedstawia średnie ocen poziomu, w jakim praca odpowiada oczekiwaniom respondentów w poszczególnych wymiarach. Ocen dokonywano na skali sześciostopniowej, gdzie 1 oznacza oceną niedostateczną, a 6 ocenę celującą odnośnie do stopnia, w jakim praca odpowiada oczekiwaniom absolwenta. 
Oceny pierwszej pracy układają się w dość wyraźną hierarchię: najmniej satysfakcjonująca okazała się praca podejmowana przez absolwentów kierunków w branży budowlanej. To ciekawy wniosek, zważywszy, że absolwenci z tego obszaru najniżej oceniali swój poziom zarobków, choć równocześnie mogli liczyć na najwyższe wynagrodzenia. W grupie absolwentów kierunków budowlanych zaobserwowano również największe zróżnicowanie wynagrodzeń. Może to sugerować, że w kształtowaniu ich oczekiwań zarobkowych i związanych z nimi ocen istotną rolę mógł odgrywać mechanizm relatywnej deprywacji. Wśród osób podejmujących pierwszą pracę najbardziej zadowoleni z niej byli absolwenci, którzy uzyskali wykształcenie w dziedzinach elektroniczno-elektrycznej, mechaniczno-górniczej oraz administracyjno-usługowej.

Wykres 16. Oceny pierwszej pracy według obszaru kształcenia absolwentów

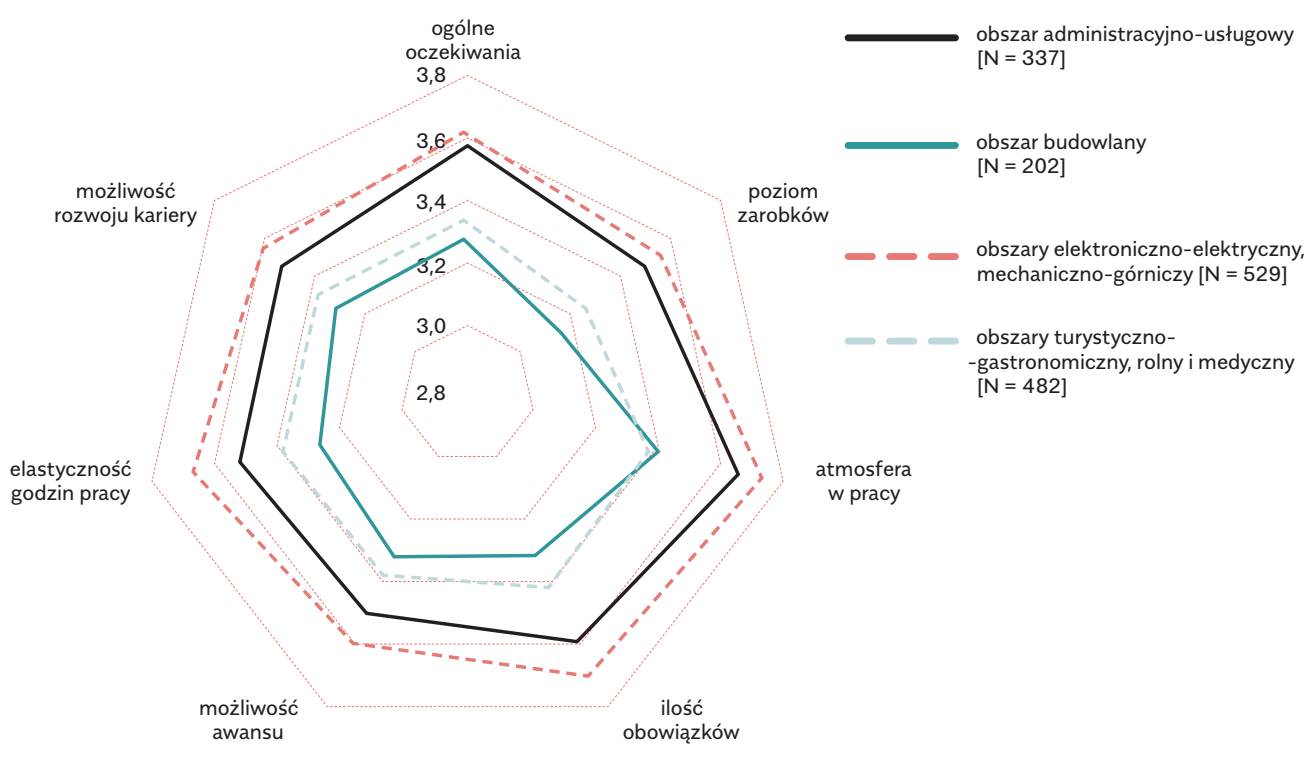

Źródło: runda pilotażowa badania MLEZAMID.

Wykres radarowy przedstawia średnie ocen poziomu, w jakim praca odpowiada oczekiwaniom respondentów w poszczególnych wymiarach. Ocen dokonywano na skali sześciostopniowej, gdzie 1 oznacza ocenę niedostateczną, a 6 celującą. 
